\title{
Synthesis, Crystal Structures and Catalytic Property of Dioxidomolybdenum(VI) Complexes with Tridentate Hydrazones
}

\author{
Xiao-Qiang Luo, ${ }^{1,2}$ Yong-Jun Han ${ }^{1}$ and Ling-Wei Xue ${ }^{1,2, *}$ \\ ${ }^{1}$ School of Chemical and Environmental Engineering, Pingdingshan University, Pingdingshan Henan 467000, P.R. China \\ ${ }^{2}$ Henan Key Laboratory of Research for Central Plains Ancient Ceramics, Pingdingshan University, \\ Pingdingshan Henan 467000, P.R. China \\ *Corresponding author: E-mail: pdsuchemistry@163.com
}

Received: 01-07-2020

\begin{abstract}
New dioxidomolybdenum(VI) complexes with the formula $\left[\mathrm{MoO}_{2} \mathrm{~L}(\mathrm{MeOH})\right]$, derived from $N^{\prime}$-(5-chloro-2-hydroxybenzylidene)-2-methylbenzohydrazide $\left(\mathrm{H}_{2} \mathrm{~L}^{1}\right)$ and $N^{\prime}$-(3,5-dichloro-2-hydroxybenzylidene)-2-methylbenzohydrazide $\left(\mathrm{H}_{2} \mathrm{~L}^{2}\right)$ were prepared. Crystal and molecular structures of the complexes were determined by single crystal X-ray diffraction method. Both complexes were further characterized by elemental analysis and FT-IR spectra. Single crystal $\mathrm{X}$-ray structural studies indicate that the hydrazones $\mathrm{L}^{1}$ and $\mathrm{L}^{2}$ coordinate to the $\mathrm{MoO}_{2}$ cores through the enolate oxygen, phenolate oxygen and azomethine nitrogen. The Mo atoms in both complexes are in octahedral coordination. Catalytic properties for epoxidation of styrene by the complexes using $\mathrm{PhIO}$ and $\mathrm{NaOCl}$ as oxidant have been studied.
\end{abstract}

Keywords: Molybdenum; hydrazine; crystal structure; hydrogen bonding; catalytic property

\section{Introduction}

The oxidation of organic compounds is an important chemical process in the chemical industry to synthesize a large variety of organic materials. Due to the slow rate of most oxidation reactions in the absence of catalysts, the catalytic oxidation of organic substrates by metal complexes has received much attention in organic synthesis. Many transition metals have been used as homogenous or heterogeneous catalysts in various oxidation systems. ${ }^{1}$ The epoxidation products of olefins have widely applications in various fields. They are intermediates or precursors for the synthesis of pharmaceuticals, agrochemicals, and many other compounds. ${ }^{2}$ Among various metal complexes, those with Mo centers have been attracted considerable attention due<smiles>Cc1ccccc1C(=O)N/N=C/c1cc(Cl)ccc1O</smiles>

$\mathrm{H}_{2} \mathrm{~L}^{1}$ to their recently discovered biochemical significance ${ }^{3}$ as well as their efficient catalytic properties in several organic synthesis procedures. ${ }^{4}$ Schiff bases are widely used as ligands in the construction of metal complexes. ${ }^{5}$ In recent years, a large number of molybdenum complexes with Schiff bases derived from salicylaldehyde and primary amines have been reported. ${ }^{6}$ Hydrazones, bearing -C(O)$\mathrm{NH}-\mathrm{N}=\mathrm{CH}-$ groups, are a kind of special Schiff bases, which are of particular interest in coordination chemistry and biological applications. ${ }^{7}$ However, due to the search of the Crystallographic Structural Database, the number of molybdenum(VI) complexes with hydrazone ligands are much less than other metal complexes with such type of ligands. In this paper, two new dioxidomolybdenum(VI) complexes with the formula $\left[\mathrm{MoO}_{2} \mathrm{~L}(\mathrm{MeOH})\right]$, derived<smiles>Cc1ccccc1C(=O)N/N=C/c1cc(Cl)cc(Cl)c1O</smiles>

$\mathrm{H}_{2} \mathrm{~L}^{2}$ 
from $\quad N^{\prime}$-(5-chloro-2-hydroxybenzylidene)-2-methylbenzohydrazide $\left(\mathrm{H}_{2} \mathrm{~L}^{1}\right)$ and $N^{\prime}$-(3,5-dichloro-2-hydroxybenzylidene)-2-methylbenzohydrazide $\left(\mathrm{H}_{2} \mathrm{~L}^{2}\right)$ are reported.

\section{Experimental}

\section{1. Materials and Measurements}

5-Chlorosalicylaldehyde, 3,5-dichlorosalicylaldehyde and 2-methylbenzohydrazide were purchased from Aldrich and used without further purification. $\left[\mathrm{MoO}_{2}(\mathrm{a}-\right.$ $\mathrm{Cac})_{2}$ ] and other solvents and reagents were made in China and used as received. $\mathrm{C}, \mathrm{H}$ and $\mathrm{N}$ elemental analyses were performed with a Perkin-Elmer elemental analyser. GC experiments were performed with Agilent 5977A Network GC systems. Infrared spectra were recorded on a Nicolet AVATAR 360 spectrometer as $\mathrm{KBr}$ pellets in the $4000-400$ $\mathrm{cm}^{-1}$ region.

\section{2. Synthesis of $\mathrm{H}_{2} \mathrm{~L}^{1}$}

5-Chlorosalicylaldehyde $(1.0 \mathrm{mmol}, 0.156 \mathrm{~g})$ and 2-methylbenzohydrazide $(1.0 \mathrm{mmol}, 0.150 \mathrm{~g})$ were dissolved in methanol $(30 \mathrm{~mL})$ with stirring. The mixture was stirred for about $30 \mathrm{~min}$ at room temperature to give a colorless solution. The solvent was evaporated to give colorless crystalline product of $\mathrm{H}_{2} \mathrm{~L}^{1}$. Yield, $91 \%$. For $\mathrm{C}_{15} \mathrm{H}_{13} \mathrm{ClN}_{2} \mathrm{O}_{2}$ : anal. calcd., \%: C, 62.4; H, 4.5; N, 9.7. Found, \%: C, 62.2; H, 4.6; N, 9.8.

\section{3. Synthesis of $\mathrm{H}_{2} \mathrm{~L}^{2}$}

3,5-Dichlorosalicylaldehyde (1.0 mmol, $0.190 \mathrm{~g})$ and 2-methylbenzohydrazide $(1.0 \mathrm{mmol}, 0.150 \mathrm{~g})$ were dissolved in methanol $(30 \mathrm{~mL})$ with stirring. The mixture was stirred for about $30 \mathrm{~min}$ at room temperature to give a colorless solution. The solvent was evaporated to give colorless crystalline product of $\mathrm{H}_{2} \mathrm{~L}^{2}$. Yield, $95 \%$. For $\mathrm{C}_{15} \mathrm{H}_{12} \mathrm{Cl}_{2} \mathrm{~N}_{2} \mathrm{O}_{2}$ : anal. calcd., \%: C, 55.8; H, 3.7; N, 8.7. Found, \%: C, 55.7; H, 3.8; N, 8.6.

\section{4. Synthesis of $\left[\mathrm{MoO}_{2} \mathrm{~L}^{1}(\mathrm{MeOH})\right](1)$}

A methanolic solution $(10 \mathrm{~mL})$ of $\left[\mathrm{MoO}_{2}(\mathrm{acac})_{2}\right]$ $(0.1 \mathrm{mmol}, 32.6 \mathrm{mg})$ was added to a methanolic solution $(10 \mathrm{~mL})$ of $\mathrm{H}_{2} \mathrm{~L}^{1}(0.1 \mathrm{mmol}, 28.9 \mathrm{mg})$ with stirring. The mixture was stirred for 20 min to give a yellow solution. The resulting solution was allowed to stand in air for a few days. Yellow block-shaped crystals suitable for X-ray single crystal analysis were formed at the bottom of the vessel. The isolated product was washed three times with cold methanol, and dried in a vacuum over anhydrous $\mathrm{CaCl}_{2}$. Yield, 63\%. For $\mathrm{C}_{16} \mathrm{H}_{15} \mathrm{ClMoN}_{2} \mathrm{O}_{5}$ : anal. calcd., \%: C, 43.0; H, 3.4; N, 6.3. Found, \%: C, 43.2; H, 3.4; N, 6.2.

\section{5. Synthesis of $\left[\mathrm{MoO}_{2} \mathrm{~L}^{2}(\mathrm{MeOH})\right]$ (2)}

A methanolic solution $(10 \mathrm{~mL})$ of $\left[\mathrm{MoO}_{2}(\mathrm{acac})_{2}\right]$ $(0.1 \mathrm{mmol}, 32.6 \mathrm{mg})$ was added to a methanolic solution

Table 1. Crystallographic data and refinement parameters for the complexes

\begin{tabular}{|c|c|c|}
\hline & 1 & 2 \\
\hline Chemical formula & $\mathrm{C}_{16} \mathrm{H}_{15} \mathrm{ClMoN}_{2} \mathrm{O}_{5}$ & $\mathrm{C}_{16} \mathrm{H}_{14} \mathrm{Cl}_{2} \mathrm{MoN}_{2} \mathrm{O}_{5}$ \\
\hline$M r$ & 446.7 & 481.1 \\
\hline Crystal color, habit & Yellow, block & Yellow, block \\
\hline Crystal size $\left(\mathrm{mm}^{3}\right)$ & $0.32 \times 0.30 \times 0.27$ & $0.20 \times 0.20 \times 0.17$ \\
\hline Crystal system & Monoclinic & Monoclinic \\
\hline Space group & $P 2_{1} / c$ & $P 2{ }_{1} / c$ \\
\hline \multicolumn{3}{|l|}{ Unit cell parameters } \\
\hline$a(\AA)$ & $7.957(1)$ & $7.961(2)$ \\
\hline$b(\AA)$ & $14.073(1)$ & $14.123(2)$ \\
\hline$c(\AA)$ & $15.172(1)$ & $15.981(2)$ \\
\hline$\beta\left(^{\circ}\right)$ & $92.767(2)$ & $92.277(2)$ \\
\hline $\mathrm{V}\left(\AA^{3}\right)$ & $1697.0(3)$ & $1795.4(6)$ \\
\hline $\mathrm{Z}$ & 4 & 4 \\
\hline$D_{\text {calc }}\left(\mathrm{g} \mathrm{cm}^{-3}\right)$ & 1.748 & 1.780 \\
\hline Temperature (K) & $298(2)$ & $298(2)$ \\
\hline$\mu\left(\mathrm{mm}^{-1}\right)$ & 0.960 & 1.058 \\
\hline$F(000)$ & 896 & 960 \\
\hline Number of unique data & 3702 & 3919 \\
\hline Number of observed data $[I>2 \sigma(I)]$ & 2963 & 3151 \\
\hline Number of parameters & 231 & 240 \\
\hline Number of restraints & 1 & 1 \\
\hline$R_{1}, w R_{2}[I>2 \sigma(I)]$ & $0.0261,0.0595$ & $0.0313,0.0688$ \\
\hline$R_{1}, w R_{2}$ (all data) & $0.0388,0.0668$ & $0.0466,0.0764$ \\
\hline Goodness of fit on $F^{2}$ & 1.080 & 1.043 \\
\hline Max and min electron density $\left(\mathrm{e} \AA^{-3}\right)$ & $0.699,-0.436$ & $0.881,-0.710$ \\
\hline
\end{tabular}

Luo et al.: Synthesis, Crystal Structures and Catalytic Property ... 
(10 mL) of $\mathrm{H}_{2} \mathrm{~L}^{2}(0.1 \mathrm{mmol}, 32.2 \mathrm{mg})$ with stirring. The mixture was stirred for 20 min to give a yellow solution. The resulting solution was allowed to stand in air for a few days. Yellow block-shaped crystals suitable for X-ray single crystal analysis were formed at the bottom of the vessel. The isolated product was washed three times with cold methanol, and dried in a vacuum over anhydrous $\mathrm{CaCl}_{2}$. Yield, $45 \%$. For $\mathrm{C}_{16} \mathrm{H}_{14} \mathrm{Cl}_{2} \mathrm{MoN}_{2} \mathrm{O}_{5}$ : anal. calcd., \%: C, 39.9; H, 2.9; N, 5.8. Found, \%: C, 40.0; H, 3.0; N, 5.6.

\section{6. Data Collection, Structural Determination and Refinement}

Diffraction intensities for the complexes were collected at 298(2) K using a Bruker Smart 1000 CCD area diffractometer with $\mathrm{MoKa}$ radiation $(\mathrm{l}=0.71073 \AA)$. The collected data were reduced using SAINT, ${ }^{8}$ and multi-scan absorption corrections were performed using SADABS. ${ }^{9}$ Structures of the complexes were solved by direct methods and refined against $F^{2}$ by full-matrix least-squares methods using SHELXTL. ${ }^{10}$ All of the non-hydrogen atoms were refined anisotropically. The methanol $\mathrm{H}$ atoms in the complexes were located in difference Fourier maps and refined isotropically, with $\mathrm{O}-\mathrm{H}$ distances restrained to $0.85(1) \AA$. All other $\mathrm{H}$ atoms were placed in idealized positions and constrained to ride on their parent atoms. The crystallographic data for the complexes are summarized in Table 1. Selected bond lengths and angles are given in Table 2.

Table 2. Selected bond distances $(\AA)$ and angles $\left(^{\circ}\right)$ for the complexes

1

\begin{tabular}{lclll}
\hline Mo1-O1 & $1.918(2)$ & \multicolumn{3}{l}{ Mo1-O2 2.012(2) } \\
Mo1-O3 & $2.360(2)$ & \multicolumn{2}{l}{ Mo1-O4 1.695(2) } \\
Mo1-O5 & $1.692(2)$ & \multicolumn{2}{l}{ Oo1-N1 2.234(2) } \\
O1-Mo1-O2 & $149.57(7)$ & O1-Mo1-N1 & $81.23(7)$ \\
O4-Mo1-O1 & $103.03(8)$ & O4-Mo1-O2 & $97.65(7)$ \\
O4-Mo1-N1 & $156.30(8)$ & O2-Mo1-N1 & $71.12(6)$ \\
O5-Mo1-O1 & $99.90(9)$ & O5-Mo1-O2 & $95.61(9)$ \\
O5-Mo1-O4 & $105.77(9)$ & O5-Mo1-N1 & $96.26(8)$ \\
O5-Mo1-O3 & $170.96(8)$ & O4-Mo1-O3 & $81.89(7)$ \\
O1-Mo1-O3 & $82.69(8)$ & O2-Mo1-O3 & $78.37(7)$ \\
N1-Mo1-O3 & $75.49(6)$ & \multicolumn{3}{l}{} \\
\hline & & 2 & \\
\hline Mo1-O1 & $1.941(2)$ & Mo1-O2 2.022(2) \\
Mo1-O3 & $2.326(2)$ & Mo1-O4 1.686(2) \\
Mo1-O5 & $1.697(2)$ & Mo1-N1 2.246(2) \\
O1-Mo1-O2 & $149.21(8)$ & O1-Mo1-N1 & $80.87(8)$ \\
O2-Mo1-N1 & $70.86(8)$ & O1-Mo1-O3 & $82.57(8)$ \\
O4-Mo1-O1 & $98.35(10)$ & O4-Mo1-O2 & $96.19(10)$ \\
O4-Mo1-O5 & $105.94(11)$ & O4-Mo1-N1 & $95.25(9)$ \\
O4-Mo1-O3 & $170.55(9)$ & O2-Mo1-O3 & $78.86(8)$ \\
O5-Mo1-O1 & $103.64(9)$ & O5-Mo1-O2 & $98.19(9)$ \\
O5-Mo1-N1 & $157.24(9)$ & O5-Mo1-O3 & $82.86(9)$ \\
N1-Mo1-O3 & $75.56(7)$ & \multicolumn{2}{c}{} \\
\hline
\end{tabular}

\section{7. General Method for Styrene Oxidation}

The oxidation reactions were carried out according to the literature method. ${ }^{11}$ The composition of the reaction mixture was $2.00 \mathrm{mmol}$ of styrene, $2.00 \mathrm{mmol}$ of chlorobenzene (internal standard), $0.10 \mathrm{mmol}$ of the complex (catalyst) and $2.00 \mathrm{mmol}$ iodosylbenzene (PhIO) or sodium hypochlorite $(\mathrm{NaClO})$ as the oxidant in $5.00 \mathrm{~mL}$ freshly distilled acetonitrile. When the oxidant was sodium hypochlorite, the solution was buffered to $\mathrm{pH}$ 11.2. The composition of reaction medium was determined by GC with styrene and styrene epoxide quantified by the internal standard method (chlorobenzene).

\section{Results and Discussion}

\section{1. Chemistry}

The complexes were prepared by mixing $\left[\mathrm{MoO}_{2}(\mathrm{a}-\right.$ cac $)_{2}$ ] with the hydrazones $\mathrm{H}_{2} \mathrm{~L}^{1}$ and $\mathrm{H}_{2} \mathrm{~L}^{2}$ in methanol. Single crystal structures were obtained by slow evaporation of the complexes in methanol. The difference of the molecular packing modes of the complexes may be caused by the hindrance effects of the chloro-substituent groups. There is only one chloro-substituent group in complex $\mathbf{1}$, while two in complex 2 . The complexes are soluble in methanol, ethanol, and acetonitrile. The molar conductance of the complexes $\mathbf{1}$ and $\mathbf{2}$ at the concentrations of $10^{-4} \mathrm{M}$ are 25 and $20 \Omega^{-1} \mathrm{~cm}^{2} \mathrm{~mol}^{-1}$, respectively, indicating they are non-electrolytes. ${ }^{12}$

\section{2. Structure Description of the Complexes}

The molecular structures and atom numbering schemes of complexes $\mathbf{1}$ and $\mathbf{2}$ are shown in Figures 1 and 2 , respectively. The coordination geometry around the Mo atoms in both complexes is highly distorted octahedral. The dianionic hydrazones $\mathrm{L}^{1}$ and $\mathrm{L}^{2}$ adopt planar tridentate manner, forming five- and one six-membered chelate rings involving the $\mathrm{MoO}_{2}$ cores. The hydrazones $\mathrm{L}^{1}$ and $\mathrm{L}^{2}$ in the complexes are bonded to the $\mathrm{MoO}_{2}$ cores in planar fashion, coordinating through the phenolate $\mathrm{O}$, imino $\mathrm{N}$, and enolate $\mathrm{O}$, and an oxo group lying trans to the nitrogen donor. In each complex, a methanol molecule completes the distorted octahedral coordination sphere which lying trans to the other oxo group. The Mo-O(methanol) bonds are significantly longer than the other $\mathrm{Mo}-\mathrm{O}$ bonds, indicating that the methanol molecules are weakly bonded to the $\mathrm{MoO}_{2}$ cores and this position holds the possibility of functioning as a substrate binding site. The atoms $\mathrm{O} 1, \mathrm{O} 2$, $\mathrm{O} 4$, and $\mathrm{N} 1$ show high degree of planarity from the equatorial plane, the Mo atoms displaced by $0.332(1) \AA$ for complex 1 and 0.320(1) $\AA$ for complex 2 toward the axial oxo groups. The $\mathrm{Mo}=\mathrm{O}$ bonds in the complexes are almost equal within the standard deviations, and are within previously reported ranges, ${ }^{4 f, 13}$ The angular distortion in the 
octahedral environment around Mo atoms come from the five- and six-membered chelate rings taken by the hydrazones $\mathrm{L}^{1}$ and $\mathrm{L}^{2}$. For the same reason, the trans angles are significantly deviate from the ideal values of $180^{\circ}$. The hydrazones $\mathrm{L}^{1}$ and $\mathrm{L}^{2}$ in the complexes are distorted, with the two benzene rings make dihedral angles of $12.6(3)^{\circ}$ for complex 1 and $9.2(3)^{\circ}$ for complex 2 . The bond lengths of C6-C7, C7-N1, N1-N2, N2-C8 and C8-O2 are comparable to those observed in similar hydrazone complexes. ${ }^{14}$

In the crystal structure of complex 1 (Figure 3), two symmetry related adjacent molecules are linked by the methanol molecules of each other through two intermolecular O3-H3A...N2 hydrogen bonds (Table 3), to form a dimeric moiety. The dimeric moieties are further linked via $\mathrm{C}-\mathrm{H}$... O interactions (Table 3 ), to form $3 \mathrm{D}$ network. In the crystal structure of complex 2 (Figure 4), two symme-

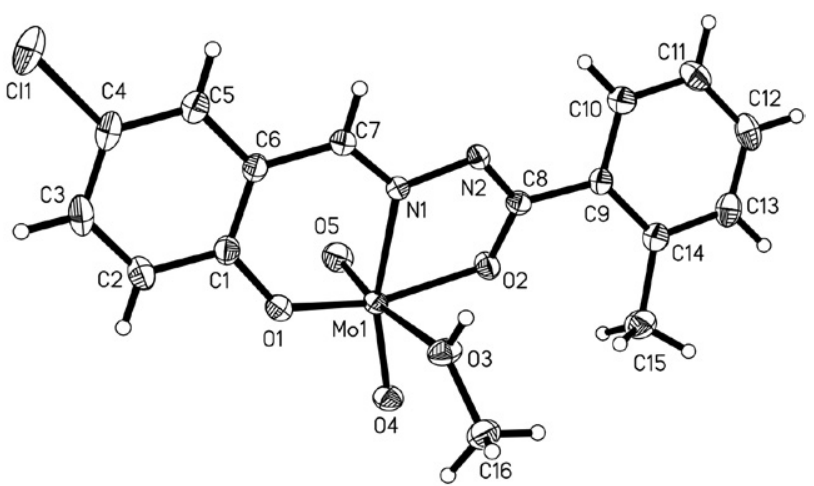

Figure 1. ORTEP plot of the crystal structure of 1 . Displacement ellipsoids of non-hydrogen atoms are drawn at the $30 \%$ probability level.

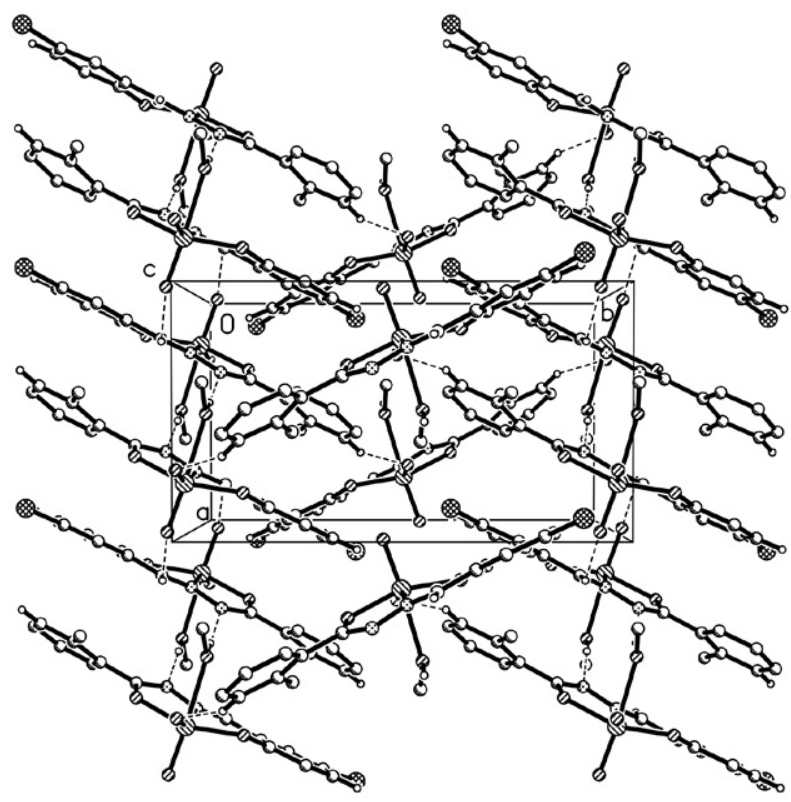

Figure 2. ORTEP plot of the crystal structure of 2. Displacement ellipsoids of non-hydrogen atoms are drawn at the $30 \%$ probability level.

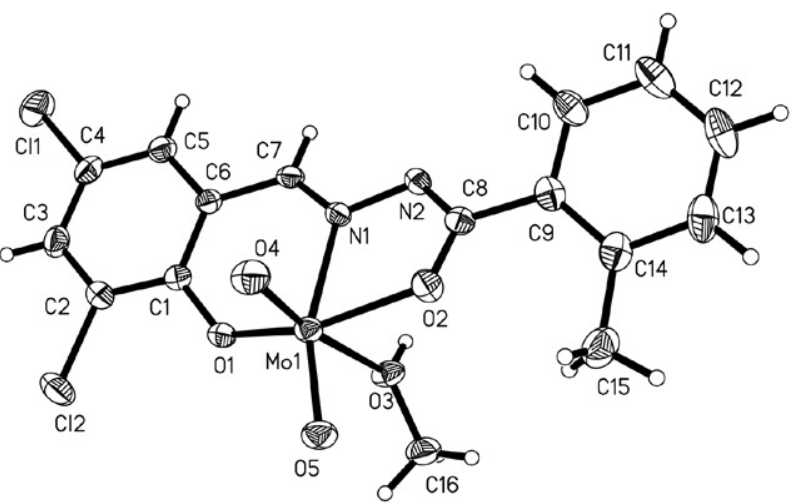

Figure 3. Molecular packing arrangement of $\mathbf{1}$ displayed in the unit cell. Hydrogen bonds are shown as dashed lines.

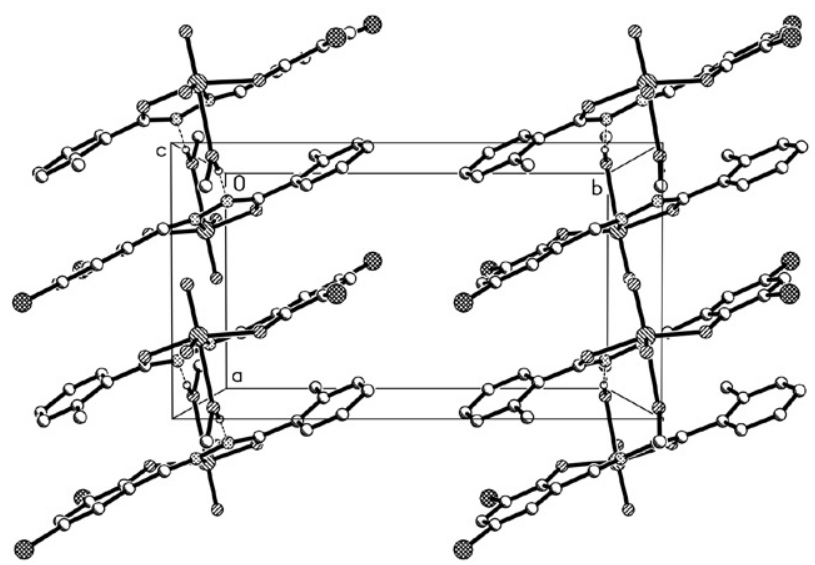

Figure 4. Molecular packing arrangement of 2 displayed in the unit cell. Hydrogen bonds are shown as dashed lines.

Table 3. Geometrical Parameters for Hydrogen Bonds

\begin{tabular}{|c|c|c|c|c|}
\hline Hydrogen bonds & D-H $(\AA)$ & $\mathrm{H} \cdots A(\AA)$ & $D \cdots A(\AA)$ & $D-\mathrm{H} \cdots A\left({ }^{\circ}\right)$ \\
\hline \multicolumn{5}{|c|}{1} \\
\hline $\mathrm{O} 3-\mathrm{H} 3 \mathrm{~A} \cdots \mathrm{N} 2^{\# 1}$ & $0.85(1)$ & $1.97(1)$ & $2.811(2)$ & $173(4)$ \\
\hline $\mathrm{C} 3-\mathrm{H} 3 \cdots \mathrm{O} 4^{\# 2}$ & 0.93 & $2.59(1)$ & $3.419(2)$ & $148(4)$ \\
\hline $\mathrm{C} 7-\mathrm{H} 7 \ldots \mathrm{O} 5^{\# 3}$ & 0.93 & $2.55(1)$ & $3.243(2)$ & $131(4)$ \\
\hline $\mathrm{C} 13-\mathrm{H} 13 \cdots \mathrm{O} 4^{\# 4}$ & 0.93 & $2.53(1)$ & $3.408(2)$ & $157(4)$ \\
\hline \multicolumn{5}{|c|}{2} \\
\hline $\mathrm{O} 3-\mathrm{H} 3 \mathrm{~A} \cdots \mathrm{N} 2^{\# 5}$ & $0.90(1)$ & $1.89(1)$ & $2.788(3)$ & $175(5)$ \\
\hline
\end{tabular}

try related adjacent molecules are linked by the methanol molecules of each other through two intermolecular O3H3A ...N2 hydrogen bonds (Table 3), to form a dimeric moiety. In addition, there are $\pi \cdots \pi$ interactions among the rings Mo1-O2-C8-N2-N1, C1-C2-C3-C4-C5-C6 and C9C10-C11-C12-C13-C14, with centroid to centroid distances of 3.67-4.58 $\AA$ for complex 1 and 3.69-4.41 $\AA$ for 
complex 2. The $\mathrm{C} 4-\mathrm{Cl} 1 \cdots \pi$ interactions between $\mathrm{Cl} 1$ atom with the ring $\mathrm{C} 9-\mathrm{C} 10-\mathrm{C} 11-\mathrm{C} 12-\mathrm{C} 13-\mathrm{C} 14$ also contribute to the crystal packing of both complexes, with distances of 3.705(3) Å for complex 1 and 3.944(3) Å for complex 2.

\section{3. Infrared and Electronic Spectra}

The hydrazones showed stretching bands attributed to $\mathrm{C}=\mathrm{O}, \mathrm{C}=\mathrm{N}, \mathrm{C}-\mathrm{OH}$ and $\mathrm{NH}$ at about $1654,1629,1150$ and 1225 , and $3253 \mathrm{~cm}^{-1}$. In addition, strong bands observed at $1612 \mathrm{~cm}^{-1}$ for $\mathrm{H}_{2} \mathrm{~L}^{1}$ and $\mathrm{H}_{2} \mathrm{~L}^{2}$ are attributed to $\mathrm{CH}=\mathrm{N}$ groups. ${ }^{15}$ Both complexes exhibit intense bands at ca. $920 \mathrm{~cm}^{-1}$, assigned to the vibrations of the $\mathrm{MoO}_{2}$ cores. ${ }^{16}$ The bands due to $v_{\mathrm{C}=\mathrm{O}}$ and $v_{\mathrm{NH}}$ are absent in the complexes, but new C-O stretches appeared at $1261 \mathrm{~cm}^{-1}$ for both complexes. Keto-imine tautomerism is present in molecules $\mathrm{H}_{2} \mathrm{~L}^{1}$ and $\mathrm{H}_{2} \mathrm{~L}^{2}$. Upon coordination to Mo atom, enol-imine tautomerism is present in ligands $\mathrm{L}^{1}$ and $\mathrm{L}^{2}$. The $v_{\mathrm{C}=\mathrm{N}}$ absorption observed at $1629 \mathrm{~cm}^{-1}$ in the free hydrazones shifted to $1603 \mathrm{~cm}^{-1}$ for the complexes upon coordination to Mo atoms. ${ }^{16}$ The weak peaks in the low wave numbers in the region $450-800 \mathrm{~cm}^{-1}$ may be attributed to Mo-O and Mo-N bonds of the complexes. ${ }^{17}$

In the electronic spectra of the two complexes, the bands ranging from 250 to $340 \mathrm{~nm}$ are assigned to $n \rightarrow \pi^{*}$ transitions, and those at $210-230 \mathrm{~nm}$ assigned to $\pi \rightarrow \pi^{\star}$ transitions. ${ }^{18}$ The bands with the maximum absorption at $400-410 \mathrm{~nm}$ are due to the ligand to metal charge transfer transition. ${ }^{18}$

\section{4. Catalytic Property}

Oxidation of styrene was carried out at room temperature with the complexes as the catalysts and $\mathrm{PhIO}$ and $\mathrm{NaOCl}$ as oxidants. The orange color of the solutions containing the complexes and the substrate was intensified after the addition of oxidant indicating the formation of oxo-metallic intermediates of the catalysts. After completion of oxidation reaction of the alkene, the solution regains its initial color which suggests that the regeneration of the catalysts takes place.

The two complexes as catalysts convert styrene most efficiently in the presence of $\mathrm{PhIO}$ or $\mathrm{NaOCl}$. There is no obvious difference for the catalytic properties between the two complexes, as a result of similar structures. The complexes are selective towards the formation of styrene epoxide. When the reactions were carried out with PhIO, styrene conversions are $83 \%$ and $85 \%$ for $\mathbf{1}$ and 2 , respectively. When the reactions were carried out with $\mathrm{NaOCl}$, styrene conversions are $71 \%$ and $74 \%$ for $\mathbf{1}$ and 2 , respectively. It is evident that between the oxidants PhIO and $\mathrm{NaOCl}$, the former acts as a better oxidant with respect to the styrene conversion. The two complexes have similar catalytic properties on the oxidation of styrene when compared to the manganese(III) complexes with the ligand $N, N^{\prime}-o$-phenylenebis(3-ethoxysalicylaldimine). ${ }^{11}$
Reaction of the oxidants with the complexes would likely generate a $\mathrm{Mo}-\mathrm{Cl}$ or Mo-I entity, which further exchange $\mathrm{Cl}$ or I for $\mathrm{ClO}$ or IO, and homolytic cleavage of $\mathrm{Mo}-\mathrm{OCl}$ or Mo-OI bond, generate effective epoxidising agent $\mathrm{ClO}$. or IO. Then, $\mathrm{ClO}$ or IO- reacts with styrene to give the styrene epoxide.

\section{Conclusion}

New dioxidomolybdenum(VI) complexes with similar hydrazones have been prepared and structurally characterized by single crystal X-ray diffraction method, as well as elemental analysis and FT-IR spectra. The hydrazones coordinate to the $\mathrm{MoO}_{2}$ cores through the enolate oxygen, phenolate oxygen and azomethine nitrogen. Methanol is a suitable solvent for the preparation of such complexes, which readily coordinates to the Mo atom as a co-ligand. Different substituent groups in the benzene rings of the ligands can result in different molecular packing modes of the final molybdenum(VI) complexes. Both complexes have similar and effective catalytic oxidation property on styrene.

\section{Supplementary Material}

CCDC-943080 (1) and 943081 (2) contain the supplementary crystallographic data for this paper. These data can be obtained free of charge at http://www.ccdc.cam. ac.uk/const/retrieving.html or from the Cambridge Crystallographic Data Centre (CCDC), 12 Union Road, Cambridge CB2 1EZ, UK; fax: $+44(0) 1223-336033$ or e-mail: deposit@ccdc.cam.ac.uk.

\section{References}

1. (a) J. A. L. da Silva, J. J. R. F. da Silva, A. J. L. Pombeiro, Coord. Chem. Rev. 2011, 255, 2232-2248;

DOI:10.1016/j.ccr.2011.05.009

(b) A. G. J. Ligtenbarg, R. Hage, B. L. Feringa, Coord. Chem. Rev. 2003, 237, 89-101;

DOI:10.1016/S0010-8545(02)00308-9

(c) Z. Moradi-Shoeili, M. Zare, M. Bagherzadeh, M. Kubicki, D. M. Boghaei, J. Coord. Chem. 2015, 68, 548-559;

DOI:10.1080/00958972.2014.993321

(d) N. C. Jana, M. Patra, P. Brandao, A. Panja, Polyhedron 2019, 164, 23-34; DOI:10.1016/j.poly.2019.02.024

(e) V. Vrdoljak, J. Pisk, D. Agustin, P. Novak, J. P. Vukovic, D. Matkovic-Calogovic, New J. Chem. 2014, 38, 6176-6185. DOI:10.1039/C4NJ01394H

2. R. Bikas, V. Lippolis, N. Noshiranzadeh, H. Farzaneh-Bonab, A. J. Blake, M. Siczek, H. Hosseini-Monfared, T. Lis, Eur. J. Inorg. Chem. 2017, 6, 999-1006. DOI:10.1002/ejic.201601359

3. (a) S. Quintal, M. J. P. da Silva, S. R. M. Martins, R. Sales, V. Felix, M. G. B. Drew, M. Meireles, A. C. Mourato, C. D. 
Nunes, M. S. Saraiva, M. Machuqueiro, M. J. Calhorda, Dalton Trans. 2019, 48, 8449-8463; DOI:10.1039/C9DT00469F (b) J. Pisk, L. Bilic, M. Dakovic, D. Cvijanovic, V. Damjanovic, J. Lovric, M. Rubcic, V. Vrdoljak, M. Cindric, Polyhedron 2018, 145, 70-79; DOI:10.1016/j.poly.2018.02.003

(c) H. Pfeiffer, M. Dragoun, A. Prokop, U. Schatzschneider, Z. Anorg. Allg. Chem. 2013, 639, 1568-1576.

DOI:10.1002/zaac.201300055

4. (a) T. Leischner, L. A. Suarez, A. Spannenberg, K. Junge, A. Nova, M. Beller, Chem. Sci. 2019, 10, 10566-10576;

DOI:10.1039/C9SC03453F

(b) M. R. Maurya, N. Jangra, F. Avecilla, N. Ribeiro, I. Correia, ChemistrySelect 2019, 4, 12743-12756;

DOI:10.1002/slct.201903678

(c) R. Tran, S. M. Kilyanek, Dalton Trans. 2019, 48, 1630416311; DOI:10.1039/C9DT03759D

(d) T. M. Asha, M. Sithambaresan, M. R. P. Kurup, Polyhedron 2019, 171, 530-541. DOI:10.1016/j.poly.2019.08.006

5. (a) K. Dankhoff, B. Weber, Dalton Trans. 2019, 48, 1537615380; DOI:10.1039/C9DT00846B

(b) H. Y. Qian, N. Sun, Transition Met. Chem. 2019, 44, 501506; DOI:10.1007/s11243-018-00296-X

(c) S. Thakur, M. G. B. Drew, A. Franconetti, A. Frontera, S. Chattopadhyay, RSC Advances 2019, 9, 35165-35175;

DOI:10.1039/C9RA07006K

(d) H. Y. Qian, Inorg. Nano-Met. Chem. 2018, 48, 615-619; DOI:10.1080/24701556.2019.1567542

(e) M. S. C. Manna, S. Mistri, A. Patra, M. K. Mahish, D. Saren, R. K. Manne, M. K. Santra, E. Zangrando, H. Puschmann, Polyhedron 2019, 171, 77-85;

DOI:10.1016/j.poly.2019.06.049

(f) H. Y. Qian, Russ. J. Coord. Chem. 2018, 44, 32-38. DOI:10.1134/S1070328418010074

6. (a) N. Monadi, E. Moradi, Transition Met. Chem. 2018, 43, 161-170; DOI:10.1007/s11243-018-0204-x

(b) M. Bagherzadeh, S. Ataie, H. Mahmoudi, J. Janczak, Inorg. Chem. Commun. 2017, 84, 63-67;

DOI:10.1016/j.inoche.2017.07.025

(c) S. Rakshit, D. Palit, S. K. S. Hazari, S. Rabi, T. G. Roy, F. Olbrich, D. Rehder, Polyhedron 2016, 117, 224-230;

DOI:10.1016/j.poly.2016.05.053

(d) G. Romanowski, J. Kira, Polyhedron 2016, 117, 352-358; DOI:10.1016/j.poly.2016.06.015

(e) Z. Moradi-Shoeili, M. Zare, M. Bagherzadeh, S. Ozkar, S. Akbayrak, J. Coord. Chem. 2016, 69, 668-677;

DOI:10.1080/00958972.2015.1137290

(f) S. Y. Ebrahimipour, H. Khabazadeh, J. Castro, I. Sheikhshoaie, A. Crochet, K. M. Fromm, Inorg. Chim. Acta 2015, 427, 52-61. DOI:10.1016/j.ica.2014.11.023

7. (a) A. A. El-Sherif, A. Fetoh, Y. K. Abdulhamed, G. M. Abu El-Reash, Inorg. Chim. Acta 2018, 480, 1-15;

DOI:10.1016/j.ica.2018.04.038

(b) H. Y. Qian, Inorg. Nano-Met. Chem. 2018, 48, 461-466;

DOI:10.1080/24701556.2019.1569689 (c) S. Parveen, S. Govindarajan, H. Puschmann, R. Revathi, Inorg. Chim. Acta 2018, 477, 66-74;

DOI:10.1016/j.ica.2018.02.022

(d) H. Y. Qian, Russ. J. Coord. Chem. 2017, 43, 780-786;

DOI:10.1134/S1070328417110070

(e) H.-Y. Qian, Acta Chim. Slov. 2019, 66, 995-1001;

DOI:10.4149/neo_2019_190112N36

(f) S. M. Soliman, J. H. Albering, M. Farooq, M. A. M. Wadaan, A. El-Faham, Inorg. Chim. Acta 2017, 466, 16-29.

DOI:10.1016/j.ica.2017.05.045

8. Bruker, SMART and SAINT. Bruker AXS Inc., Madison, Wisconsin, USA (2002).

9. G. M. Sheldrick, SADABS. Program for Empirical Absorption Correction of Area Detector, University of Göttingen, Germany, 1996.

10. G. M. Sheldrick, SHELXTL V5.1 Software Reference Manual, Bruker AXS, Inc., Madison, Wisconsin, USA, 1997.

11. S. Majumder, S. Hazra, S. Dutta, P. Biswas, S. Mohanta, Polyhedron 2009, 28, 2473-2479.

DOI:10.1016/j.poly.2009.04.034

12. W. J. Geary, Coord. Chem. Rev. 1971, 7, 81-122.

DOI:10.1016/S0010-8545(00)80009-0

13. (a) M. Bagherzadeh, M. Zare, V. Amani, A. Ellern, L. K. Woo, Polyhedron 2013, 53, 223-229;

DOI:10.1016/j.poly.2013.01.054

(b) M. Ghorbanloo, R. Bikas, G. Malecki, Inorg. Chim. Acta 2016, 445, 8-16; DOI:10.1016/j.ica.2016.02.018

(c) Z. Moradi-Shoeili, M. Zare, S. Akbayrak, S. Ozkar, Transition Met. Chem. 2017, 42, 357-363.

DOI:10.1007/s11243-017-0139-7

14. (a) R. Dinda, P. Sengupta, S. Ghosh, H. Mayer-Figge, W. S. Sheldrick, J. Chem. Soc., Dalton Trans. 2002, 4434-4439; DOI: $10.1039 /$ b207129k

(b) S. Alghool, C. Slebodnick, Polyhedron 2014, 67, 11-18; DOI:10.1016/j.poly.2013.08.059

(c) R. Dinda, S. Ghosh, L. R. Falvello, M. Tomas, T. C. W. Mak, Polyhedron 2006, 25, 2375-2382.

DOI:10.1016/j.poly.2006.02.002

15. P. Paciorek, J. Szklarzewicz, A. Jasińska, B. Trzewik, W. Nitek, M. Hodorowicz, Polyhedron 2015, 87, 226-232.

DOI:10.1016/j.poly.2014.11.018

16. (a) T. M. Asha, M. R. P. Kurup, Polyhedron 2019, 169, 151161; DOI:10.1016/j.poly.2019.04.045

(b) S. Gupta, A. K. Barik, S. Pal, A. Hazra, S. Roy, R. J. Butcher, S. K. Kar, Polyhedron 2007, 26, 133-141.

DOI:10.1016/j.poly.2006.08.001

17. (a) T. Glowiak, L. Jerzykiewicz, J. M. Sobczak, J. J. Ziolkowski, Inorg. Chim. Acta 2003, 356, 387-392;

DOI:10.1016/S0020-1693(03)00301-3

(b) M. R. Maurya, L. Rana, F. Avecilla, Inorg. Chim. Acta 2015, 429, 138-147; DOI:10.1016/j.ica.2015.01.040

(c) E. Zamanifar, F. Farzaneh, J. Simpson, M. Maghami, Inorg. Chim. Acta 2014, 414, 63-70. DOI:10.1016/j.ica.2014.01.028

18. H.-Y. Liu, Y.-S. Yin, L.-J. Yang, X.-L. Zou, Y.-F. Ye, Acta Chim. Slov. 2020, 67, 130-136. DOI:10.17344/acsi.2019.5286 


\section{Povzetek}

Sintetizirali smo nove dioksidomolibdenove(VI) komplekse s formulo $\left[\mathrm{MoO}_{2} \mathrm{~L}(\mathrm{MeOH})\right] \mathrm{z}$ uporabo ligandov $N^{\prime}$-(5-kloro-2-hidroksibenziiden)-2-metilbenzohidrazid $\left(\mathrm{H}_{2} \mathrm{~L}^{1}\right)$ in $N^{\prime}$-(3,5-dikloro-2-hidroksibenziliden)-2-metilbenzohidrazid $\left(\mathrm{H}_{2} \mathrm{~L}^{2}\right)$. Z rentgensko analizo na monokristalu smo določili kristalno in molekulsko strukturo obeh kompleksov. Obe spojini smo karakterizirali tudi z elementno analizo in FT-IR spektroskopijo. Strukturna analiza je pokazala, da se hidrazona $\mathrm{L}^{1}$ in $\mathrm{L}^{2}$ koordinirata na $\mathrm{MoO}_{2}$ orko enolatnega kisika, fenolatnega kisika in azometinskega dušika. Atomi Mo so v obeh spojinah oktaedrično koordinirani. Preučevali smo katalitske lastnosti obeh spojin pri epoksidaciji stirena $\mathrm{z}$ uporabo oksidantov $\mathrm{PhIO}$ in $\mathrm{NaOCl}$. 